\title{
Frémiet's frenzy
}

Nineteenth-century museum sculptures depicting great moments in prehistory might seem kitsch to modern eyes. But, in their time, they were a key way for the latest scientific ideas to be communicated to the public.

\section{Martin Kemp}

7 he Jardin des Plantes in Paris is far more than a garden of plants. In the heyday of Lamarck, Geoffroy de SaintHilaire and Cuvier, it was an international crucible for scientific natural history, and the centre for controversies about the great prehistoric transformations that studies of the fossil record were revealing. Comparative anatomy, the chair occupied by Cuvier from 1795 , was at the centre of the intellectual conflagrations.

In the Jardin today, the Gallerie d'Anatomie Comparée confronts the visitor with a striking testimony to Cuvier's legacy and to its subsequent Darwinian transformation. Constructed by the architect Ferdinand Dutert, the gallery opened in 1898 with displays devised by Albert Gaudry, the leading French advocate of Darwin's theories. On the first floor are the palaeontological collections, arranged according to evolutionary principles, while on the ground floor the visitor is immediately faced by a veritable Noah's Ark of marching skeletons, headed triumphantly by a painted écorché statue (an anatomical figure in which the muscles are revealed) of an upwardly aspiring man.

Less regarded today, but no less integral to the gallery's message, are the sculptural adornments found outside and inside the building. The leading participant was

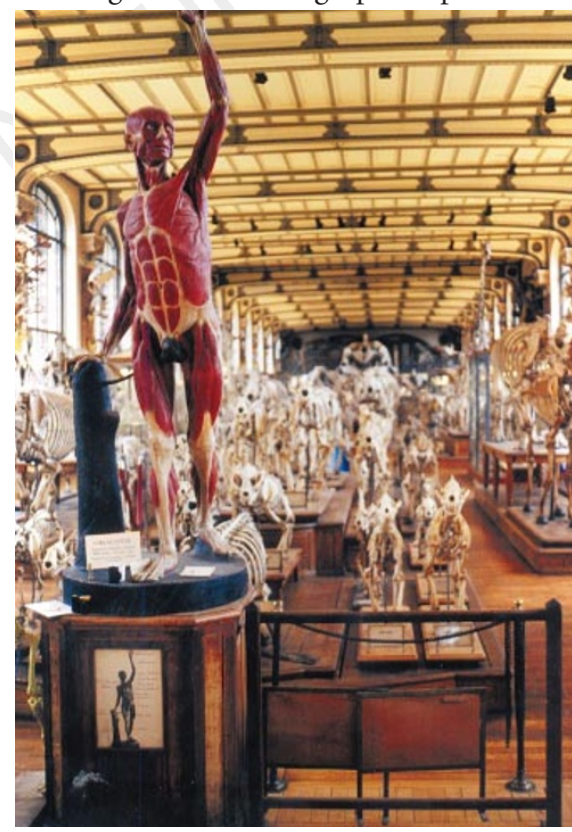

Follow me: Ecorché Man Leading the Parade of Animal Skeletons, from the Gallerie d'Anatomie Comparée, Jardin des Plantes, Paris.

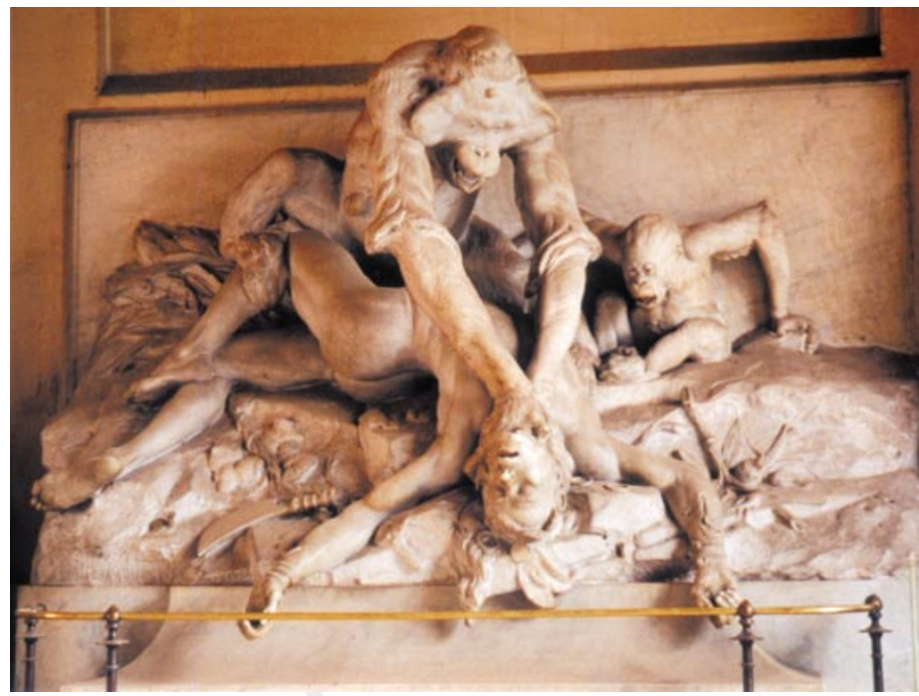

Emmanuel Frémiet, $A n$ Orang-utan Strangling a Native of Borneo, 1898, in the foyer of the Gallerie d'Anatomie Comparée.

the specialist sculptor of military and animal subjects, Emmanuel Frémiet, who had succeeded the great animalier, AntoineLouis Barye, as Professeur d'Iconographie Naturelle at the Jardin in 1875.

Famed for his equestrian monument to Joan of Arc in the Place des Pyramides, Frémiet's animal tableaux courted controversy. His favourite subjects represented humans and animals in frenzied competition: initially as realizations of French theories of the dynamic march of human history, latterly in a Darwinian context.

In the foyer is one of his stock images of natural violence, An Orang-utan Strangling a Native of Borneo, originally enhanced with polychrome touches of gore. One of his exterior bronze reliefs, on the facade overlooking the Rue Buffon, depicts a key combat in evolutionary iconography, the hard-won triumph of man over bear. The relief itself, scoured by acid rain, can now best be appreciated via the smaller version adorning the reverse of the plinth of the memorial statue erected in front of the gallery.

Victory over the bear, not least in the battle for supremacy as cave-dwellers, was seen as a vital step in human progress. Louis Figuier's popular L'homme primitif in its 1870 edition illustrates competition with the 'great bear' which lends its name to the first of his stone-age epochs. It was the advent of tools, such as the hafted axe slung over the shoulder of Frémiet's Herculean caveman, that enabled humans to "repulse the attacks of ferocious animals which prowled around his retreat and often assailed him," to quote the English translation of 1872.

In the smaller bronze, one of the sculp-



Emmanuel Frémiet, Man Triumphant over Two Bears, Jardin des Plantes.

tor's bears hangs limply over the base of the relief, mortally wounded by a broken spear, while a youngster is hauled away, literally, by the scruff of its neck. The heroic man strides forth, beard thrust resolutely into the distance, marching irresistibly towards the rising sun of the new age (a detail less apparent in the larger relief).

We may now be inclined to see such images as pieces of decorative nonsense, if we notice them at all. In fact, they were as important in the public understanding of science as any of the museum's displays, and have, particularly through related book illustrations, done much to fire the public imagination and inspire fledgling palaeontologists. We exclude such works from our concept of mainstream scientific endeavour at the risk of severely misunderstanding the public dynamic of the scientific vision.

Martin Kemp is in the Department of the History of

Art, University of Oxford, 35 Beaumont Street,

Oxford OX1 2PG, UK. 